\author{
KRZYSZTOF ŁUSZCZEK \\ Chen Chen
}

\title{
The impact of social media on fulfilling identity needs of a person - the case of China
}

\begin{abstract}
In order to live a normal life, a person must answer the question about themselves - about their image, worldview, capabilities. Typically, one's identity is built on the basis of the opinions of the environment. A person either compares themselves with it or uses the opinions of people who are important to them. In this way, the person builds their own inner continuity, which provides them with a sense of stability. It is a dynamic process which very often determines the colour and complexity of human life. Today, the closest environment are more and more often the social media. Especially for young people, they are becoming an important source of information about themselves and the world. Yet to what extent do social media offer opportunities for authentic manifestation of one's self, and to what extent do they become a space for creating parallel identities? Young users are eager to use social media, which influence their lives and identities. The problem is illustrated with the example of China, a large and original social media market.
\end{abstract}

Keywords: identity, social media, interpersonal communication, China

\section{Introduction}

For a sense of self-confidence about life and a sense of existential security, a person needs to acquire "knowledge of oneself". It is a process that lasts practically the entire lifetime, but gains a special dynamic in childhood and adolescence (although it can be discussed even already in the context of infancy). Immediately after birth, even if a child could speak, they would not be able to answer the question "Who am I?", but still such a child contains the potential to shape their identity, which will be revealed throughout their life (Bornstein, 2014).

The child self-realizes in a special way through interpersonal communication. S.W. Smith and S.R. Wilson point out that one of the new and particularly important directions of research into interpersonal communication 
is its technological entanglement. Technology has specific implications for meeting identity needs and changes the dynamics of this process (2010). It is therefore justified to undertake research into the impact of the media on building human identity. All the more so as media reality is changing rapidly and the pace of these changes often goes far beyond the forecasts made years ago. Technology often puts a person in situations for which they are not entirely prepared (Hansen, 2020). By facing them, they build their identity in a completely different way than even thirty years ago, at a time when the Internet was just beginning to gain global momentum.

A heuristic approach to an issue allows to learn new facts and, above all, discover the relationships between them. This is especially important in media research, where changes occur very quickly. In addition, the media force certain changes in social life, which also take place faster under their pressure. The heuristic method makes it possible to seek out logical connections between changes in the media market and the transformation within the social order (Kahneman, 2013).

\section{Identity and identity needs}

A question "Who am I?" results from being human and having the ability to reflect. It is located in a series of philosophical questions such as "When did I start to exist?" or "What awaits me after death?" The Stanford Encyclopaedia of Philosophy emphasizes the existence of many different definitions of human identity. The broad discussion on this issue is positioned between the placement of the concept of identity on physical and psychological continuity (2020). In the study of the impact of communication on identity, definitions highlighting psychological continuity seem more useful. According to this approach, "identity can be regarded as a unique, individual-specific and relatively stable way of defining, understanding and experiencing oneself, which is an expression of the desire to achieve personal autonomy and internal integration. Identity as such constitutes the individuality and uniqueness of each person" (Kwapis and Brygoła, 2013) [own translation].

Therefore, identity, in psychological terms, is the subjective attitude of a person to themselves, their ability to define themselves, their own values and a sense of belonging to a group with similar beliefs, while at the same time being aware of their own distinctness. Searching for answers to the question "Who am I?" becomes more and more conscious to finally reach a critical moment during the period of adolescence (Sokal, 2000). Accord- 
ing to Z. Bauman, identity should be created rather than discovered. This involves some work to be done. It does not end when you obtain a certain status quo. Identity is not so much fluid but rather dynamic, so it demands fight and protection (Bauman, 2007).

The sense of relative unchangeability (constancy, continuity) of oneself, despite the passage of time and changes in personality, is an important psychological indicator of one's own individual identity. Striving to build it is a truly human need that grants the basis for stable development and action. Identity needs cannot be changed, replaced, suppressed or negotiated (Caroll, 1988).

Identity is important to a person for many reasons. We can talk about ensuring our inner sense of cohesion, the need to define our relationship with the world, but one of the most important reasons is the pursuit of autonomy. The fundament of this process is seeing oneself as someone separate, valuable. When confronted with new challenges, a person "is tested" and acquires knowledge about themselves, becoming not only an autonomous, but also an individual, a unit. The cases of the so-called wild children (e.g. a boy from Aveyron) show that people who had no chance to shape their identity have no idea about themselves, they cannot say anything about themselves. Identity is essential to building not only the image of oneself, but also the social relationships. T. Paleczny emphasizes the special role of cultural identity as a kind of social binder of individuals. It gives the components of identity "the order and meaning" (Paleczny, 2008, p. 22).

Interpersonal communication (Fogel, 2002) is the most common source of knowledge about ourselves and means to fulfil identity needs.

Some of the elements of the built identity are self-image and self-esteem. Self-image is a relatively constant set of self-imaginings. Self-esteem is a part of the self-image. Whether it is high or low has a huge impact on communication processes. People who feel good are positive about their own communication skills (Adler, 2006).

The self-image is shaped throughout the course of personal development. At the time of the birth the child has no such image yet. Even if the child could speak, they would not be able to answer the question "Who am I?" Around the sixth or seventh month, the child begins to perceive themselves as a separate being. At this time, children begin to get fascinated with parts of their body, e.g. a hand or a foot. They start to be convinced that: "this foot is me, this hand is me." As the child develops, this sense of identity and selfautonomy becomes more and more pronounced (Wachs, 1992). 
Self-image formation has its own social context. Sociological research focuses on different mechanisms of building self-image than psychological research, which focuses on the individual's experience of oneself. Nevertheless, both of these research trends complement each other perfectly (Ackerman, 2020). For sociological experience, particularly important are the interactions between the individual and the social environment. R.B. Felson pointed out that some people have a positive effect on our self-esteem and others - a negative one. The self-image is shaped under the influence of the assessments of our environment (1985). Of particular importance here are the so-called significant persons, such as parents, husband, wife, friend, colleagues. Parents influence the self-image of their children from an early age. Children will try to imitate a parent that has a positive image, and in the situation of lack of one, they will look for a pattern outside the family. How important we consider various characteristics depends to a large extent on the opinions of others (Felson, 1989).

Another way to explain the construction of a self-image is comparing oneself to others. We build our self-image by comparing ourselves to others. That is why the type of reference group we find is so important. People often apply unreasonable standards to that. Some comparisons can be painful and destroy healthy competition. The greater the importance of certain values for self-image, the higher the level of competitiveness. However, we usually select people who are close to our ways of acting and values for comparisons (Suls and Wheeler, 2000).

Self-image is a subjective matter. This is why the lack of realism is likely to occur. Sometimes it can be over-idealized, other times people exaggerate with severity. Maintaining the myth of perfection in children and denying them the right to commit mistakes may have a negative influence on their development (Adler, 2006).

The self-image is shaped throughout the course of life. By the age of 24, the self-image is dynamic and developing. After 30, this image stabilizes. Of course, it does not mean that it will not change at all anymore. A person changes and so changes their self-image. Hence, it has a kind of flexibility, but on the other hand, it is stable enough to resist change. A certain image of ourselves that we acquire is difficult to change, so we are more likely to look for people who will confirm it. This tendency to seek affirmative information is called cognitive conservatism. It is possible to overcome such an attitude, but only if the information is perceived as competent, personal, justified in the sense of what we think of ourselves, coherent and abundant (Greenwald, 1995). 
Another communication problem that concerns building other people's image is a self-fulfilling prophecy. It is a situation where the original subjective belief about other people leads to actions that objectively confirm these beliefs. They are often false in nature and may have been suggested by third parties. Particularly many studies have focused on the occurrence of selffulfilling prophecies in close relationships, such as ones between parents and children or teachers and students. They become important for understanding the relationship between social beliefs and social reality. A self-fulfilling prophecy can also apply to oneself (Buller, 2001). In many cases, it can become a mechanism for disseminating social stereotypes. It can play the role of a sort of placebo in building identity needs (Rosenthal and Jacobson, 1968).

People use certain mechanisms to verify or confirm their identity. Their choice depends on whether it is built on a social role, a group or certain selected categories. By acting this way, people build and maintain a social structure in which identities are embedded. People can modify their identities to achieve specific communication goals. Some are more flexible and the others - less. A higher level of such skills may result from certain innate characteristics or be an outcome of appropriate preparation (Stewart and Logan, 1998).

A variety of tools can be used to modify one's identity. How the identity is controlled largely depends on which channel is chosen. Yet there are a few things we should pay attention to. They include a behaviour that consists of words and nonverbal actions. Another element is the appearance. Sometimes it builds a certain professional image. With the outfit we pass information about ourselves. Another element is the place and the surroundings. One such very telling element of the environment is a car (Adler, 2007).

To understand identity, it is important to capture its dynamics, which makes identity require a kind of monitoring, following current life and developmental situation of an individual (Kwapis and Brygoła, 2013). Education is an important tool in shaping it. School is a natural environment in which identity is shaped. Factors such as where we come from, according to what principles we were raised by parents and family, affect the initial shape of our identity. Our self-image evolves throughout the course of education, in contact with the school community, and through the influence of others, both peers and teachers. Educators must skilfully influence students in such a way that they do not lose their distinctive identity traits. Students must be convinced of their own individuality, but have respect for others (Babiarz and Garbuzik, 2017). 


\section{Media as an identity building tool}

Young people live in a world dominated by mass media which become an integral part of their lives and create their own self-image. Thus, it is the task of teachers to properly prepare their students for the rational and ethical use of pop culture so that they can draw positive patterns from it, while at the same time protect them from all the dangers that can go with it (Babiarz and Garbuzik, 2017).

Communication is now under intense pressure of technology. Technology-mediated communication plays an increasingly important role in mutual relations. Somehow, this situation was predicted already decades ago, by one of Apple's founders, Steve Jobs. After his departure from Apple to the NeXT company, he announced a new vision for creating what he called "interpersonal" computers. While Apple was creating "personal" computers that were focused on human-machine interaction, $\mathrm{NeXT}$ was supposed to create "interpersonal" computers the essence of which would be people interacting with other people through the machine. Jobs decided that such changes would take place the fastest in academia and then in business. He considered that "interpersonal" computers would revolutionize communication between people as well as their work (Siegler, 2020).

Interpersonal relationships become crucial for building a human identity. The increase in technology-mediated interaction results in a reduction in the number of direct interpersonal relationships. This way, social media gain increasing influence on identity formation and self-understanding (Ganda, 2014). Popular culture also perpetuates the belief that identity can be shaped through new technologies. In the well-known film "You've Got Mail" with T. Hanks and M. Ryan, email plays a major role in shaping the main character's alternate identity ("You've Got Mail" directed by N. Ephron, USA 1998).

However, the development of social media has caused some difficulties when it comes to interactions. There is often an unspecified number of communication partners. For example, if you communicate through Facebook, you often deal not only with the profile owner, but also with others who were invited to join it. Who is the author of the retweeted message? Who owns the digital footprints on social media accounts? When we enter relationships by means of social media, we are dealing with numerous speakers who send us their messages. Communication via social media is a testament to the intensive development of one of the most important features of digital media - hy- 
pertextuality. Some media functions become an extension of a person. Is the memory of contacts in your smartphone not a prosthesis of human memory? Is this conducive to building a human identity and a coherent self-image, or rather does it build a universal identity based on completely new criteria, bypassing factors such as language or country of origin? (Baldauf, 2017)

The importance of social media increases at certain critical moments of human life. For example, in the case of students who leave their home areas to live in an environment that is completely new to them. This creates a certain tension between identification with the old and the new environment in building one's identity based on the media. On the other hand, social media give the opportunity to explore a new environment and present oneself even before we physically find ourselves in a new space. This can have a positive effect on reducing uncertainty, but can also speed up processes of social comparisons. Hence the desire to "improve" one's image on social profiles both in terms of external appearance and presented lifestyle. Participating in social media can therefore result in self-presentation fears (Thomas, 2017).

Social media are a very dynamic part of the media market. There are not only new features, but also new platforms. Users do not typically wonder how setting up a profile on a new platform can affect their lives. Issues related to privacy, disclosure of personal information, or security usually arise only later. Online communication is often approached without any reflection, as a kind of "technological enthusiasm" raises above it. Usually, the damage suffered forces reflection and brings concrete action. What is obvious in offline life is often far from online reality (Terras, 2015).

Social media are changing the approach to meeting people's identity needs as they create new needs and show the way to fulfil them. This is primarily the ability to create multiple parallel identities. Even trying to transfer real life to a social account is often inauthentic. It is more an attempt to created images than a reflection of real reality (Akbari, 2018).

It seems that social media have a big problem with authenticity. It is enough to analyse profile pictures. Authenticity on social media is under pressure. Therefore, the identity being shaped through them is also under pressure. It is more a project in the realization than a state, an identity of "imagination" than "reality", more how we want to see ourselves than how we do see ourselves. So will the pressure of social media not make it difficult for us to define our own identity in the real world? The ubiquity of technology can cause difficulties with building their identity for millions of people. This can be well observed in the Chinese market, which is not only one of the 
largest in the world but has also built a segment of social media alternative to the rest of the world.

\section{Human identity and media in China}

The Internet is an inseparable part of everyday life for younger generations (people who were born approximately after 1990). The widespread usage of social media makes the youth develop a kind of Internet Addiction Disorder which affects the shaping process of their personal identity. Identity consists of certain unique character qualities of an individual or a group, it also includes the awareness of the social position that people belong to and role they play as members of the society. Many modern media users depend on the media emotionally, to the extent that it generates a sense of loneliness in the real life and creates confusion between virtual and real roles that they play. The following examples will be focused on showing how the youth construct their self-image in the modern media era and what kind of dilemma the youth face in the process of identity construction.

$80 \%$ of the active users Sina Weibo, Redbook and Tiktok (social media websites similar to Facebook and YouTube) are teenagers and young adults. When interacting with others online, one can judge whether the person meets one's requirements for being friends by browsing through their posts on the Internet and viewing the comments they made. Users can fill their profile on Weibo with information to introduce themselves. For example, to show off their job, hobbies and so on, which provides others with easily accessible information about them. This, however, creates two particular problems.

The first problem is that interpersonal communication skills of young people are worsening. Everything is available online so asking questions and making friends in real life becomes more difficult. Cyberspace provides users with means to construct their image through online presentation. Individuals can project their self-image through the content they share and make on the Internet. Thanks to that, individuals can be found by strangers with the same interests or hobbies. It is extremely easy to make friends online and on one hand that is a good thing. However, on the other hand it cripples the real-life communication skills and creates issues with self-image. It is possible that an outgoing and talkative person online would be very shy and quiet in the offline situations. People who were born between 1990 and 2003 stated that they can find people with similar or even the same interests through the production and dissemination of pictures and short videos. When asked about 
the reasons for this, they said that people with similar interests will find and watch their videos of their own accord (Jinfeng and Shuhui, 2020). In this way they can build a community of like-minded people really quickly.

The second problem is that with the help of the Internet, the youth can play the role they had always wanted but could not play in real life. Individuals perform selective identity on the social media for two intentions, to depict themselves in a way that is congruent with their ideal-self and to cater the online audience. Some critical remarks and articles are showing that the virtual self of college students is one they do not dare to express offline. To a certain extent, the process of virtual image construction affects the creation of the self-image. It is easy to see how one is perceived online or even assume a completely different personality. From the psychological perspective, the feeling of inadequacy and dissatisfaction lead to a reverse image (Stanton, 2016). In extreme cases, people who are kind and cultured in real life can act like barbarians using vulgar language in the cyberspace. It is the freedom of new media that gives users a possibility to perform and express themselves with a simple account login. It removes the limitations that are present in real life such as age, gender and education.

Most of Weibo users hide their real data. Wang (2006) once conlcuded this pheomenon as identity deception. Users are known to be deceptive, for instance about their name, gender or age. Online anonymity provides users with a comfortable atmosphere of expression. Users do not have to worry about making a bad impression on others due to improper words and phrasing. There are two trends about the identity construction in the media era. The first one is to extend the lives on the Internet so that other users can understand them better by, for example, sharing some important moments. This is almost the same as in real life. The second and common one is to reconstruct the identity by taking advantage the anonymity feature of social media that allows users to reshape themselves without any concern. For example, an introvert people can be talkative on the internet. Users reconstruct their own identity and want to get the acceptance and confirmation from others.

Social media is an indispensable part in the youth's social lives. The youth use the social media to build new peer affiliations, manage existing relationships and inform about social activities (Boyd, 2014). Users are often divided into different groups according to their attitudes towards something that happened recently, peers synchronize the perception of shared context in the social media group. In the process of discussion, they can change their stances at any time, thus changing the group they belong to. The users' at- 
titudes towards a certain event always change along with opinions of other members, which is called conformity. This is especially visible in China because people here generally do not like conflict and do not want to stand out. When members of the group share content, the other peers of that group will develop synchronized affinity towards the content (French, 2017). Group identity is a part of individual self-identity.

National identification is a positive feeling or the recognition of social interaction which involves the feeling of belonging to a national community and understanding the rights and duties of being a nation's citizen. National identity can create a sense of belonging among the community members in the society. In China, one can find many posters and short slogans that affect the group identity construction. Short TV programmes in the metro or in the bus provide a concise message about social values. This is to inform people or awaken their awareness to be more civilized and make efforts for a better city.

Chinese studies show that social media satisfy vital identity needs of the Chinese youth. They give young people a sense of belonging. They allow people to identify themselves with specific worldviews and beliefs. They also make it possible to quickly change views along with the changes in the group one identifies with. Social media become a place of creating one's own image. Sometimes this involves creating an alternative to who someone is in everyday life. But even more often, it involves extending one's life to happen in the virtual reality, which is becoming increasingly more attractive and seems to offer more possibilities.

\section{Conclusions}

The Chinese social media market is huge and has certain distinct characteristics. Over the years it has been built as an alternative to the global system. Despite the pressure of global media corporations, Chinese services, e.g. Weibo or Redbook, are as popular as Facebook and YouTube. Moreover, the direction of expansion in recent years has been reversed. The Chinese TikTok application has grown to become a global tycoon within four years, and almost half of its two billion users are younger than 24 (Paul, 2020).

Social media have changed the way individuals fulfil their identity needs. In many cases, they further removed the natural sources of identity building, which were primarily related to the family environment. The social media environment is dynamic, changing rapidly, and carrying various trends. This 
can trigger some discontinuities and changes in the way identity needs are met, especially among young people. Undoubtedly there is a need for further research, especially on the impact of social media platforms on identity building understood as psychological continuity. While social media contribute to building certain social relationships, where we can even talk about overabundance, the issue of internal cohesion can lead to a kind of "digital schizophrenia". The temptation to build parallel identities seems to be strong when the tools are at our fingertips. This can lead to a situation where this identity prevails over the real life.

\section{Bibliography}

Ackerman, C.E. 2020. What is self-concept theory? Psychologist explains. https://positivepsychology.com/self-concept (11.12.2020).

Adler, R.B., Rosenfeld, L.B. and Proctor II, R.F. 2007. Relacje interpersonalne. Proces porozumiewania się. Poznań: Dom Wydawniczy Rebis.

Akbari, A. 2018. Identity in the age of social media. https://www.psychologytoday.com/us/blog/startup-your-life/201809/identity-in-the-age-socialmedia (21.01.2021).

Babiarz, M. and Garbuzik, P. 2017. Tożsamość. Istotny element realizacji potrzeb rozwojowych i edukacyjnych. Edukacja - Technika - Informatyka. 3 (21), pp. 23-32.

Baldauf, H., Develotte, Ch. and Ollagnier-Beldame, M. 2017. The effects of social media on the dynamics of identity: discourse, interaction and digital traces. Alsic. 20 (1). https://journals.openedition.org/alsic/3004 (20.01.2021).

Bauman, Z. 2007. Tożsamość. Rozmowy z Benedetto Vecchim. Poznań: Wydawnictwo Nauka i Innowacje.

Bornstein, M.H. 2014. Human infancy... and the rest of the lifespan. Annual Review of Psychology. 65, pp. 121-158.

Boyd, D. 2009. Why youth social network sites: the role of networked publics in teenage. https://poseidon01.ssrn.com/delivery.php?ID=25810 5111101107124127120015026110088038002035054002027096003001 102001120002126094071043103049011103001110085111016021117 1060900580170080150720840051020781260291200720400510020881 00119109069125123006103064012067023112114005096126123069001 090122089081\&EXT =pdf\&INDEX=TRUE (04.02.2021). 
Buckingham, D. 2007. Youth, identity, and digital media. Cambridge: MIT Press.

Buller, A.A., Madon, S., Scherr, K. and Willard, J. 2021. Self-fulfilling prophecies. In: International Encyclopedia of the Social\&Behavioral Sciences. Amsterdam: Elsiver. https://www.encyclopedia.com/social-sciences/appliedand-social-sciences-magazines/self-fulfilling-prophecies (20.01.2021).

Caroll, D.J., Rosati, J.A. and Coate, R.A. 1988. Human needs realism: a critical assessement of the power of human needs in world society. In: Coate, R.A. and Rosati, J.A. ed. The power of human needs in world society. Boulder, CO: Lynne Rienner Publisher, pp. 257-274.

Felson, R.B. 1989. Parents and the reflected appraisal process: a longitudinal analysis. Journal of Personality and Social Psychology. 56, pp. 965-971.

Felson, R.B. 1985. Reflected appraisal and the development of self. Social Psychology Quarterly. 48, pp. 71-78.

Fogel, A., de Koeyer, I., Bellagamba, F. and Bell, H. 2002. The dialogical self in the first two years of life: Embarking on a journey of discovery. Theory and Psychology. 12, pp. 191-205.

French, A.M. 2017. Let's meet offline: a mixed-method approach exploring new trends in social networking. Information Technology E People. 4, pp. 946-968 .

Ganda, M. 2014. Social media and self: influence on the formation of identity an understanding of self through social networks sites. University Honors Theses. 55. https://pdxscholar.library.pdx.edu/cgi/viewcontent.cgi?articl $\mathrm{e}=1064$ \& context $=$ honorstheses $(20.01 .2021)$.

Greenwald, A.G. 1995. Getting (my) self info social psychology. In: Brannigan, G.G. and Merrens, M.R. eds. The social psychologists: research adventures. New York: McGraw-Hill, pp. 3-16.

Hansen, A. 2019. Skärmhjärnan. Stockholm: Bonnier Fakta.

Kahneman, D. 2013. Thinking, fast and slow. New York: Farrar, Straus and Giroux.

Kwapis, K. and Brygoła, E. 2013. Tożsamość osobista w ujęciu emotywno-refleksyjnym: zawartość, funkcje i procesy kształtowania tożsamości. Opuscula Sociologica. 4, pp. 33-49.

O'Sullivan, P.B. 2000. What you don't know won't hurt me: Impression management functions of communication channels in relationships. Human Communication Research. 26, pp. 403-431.

Paleczny, T. 2008. Socjologia tożsamości. Kraków: Wydawnictwo Krakowskie Towarzystwo Edukacyjne. 
Paul, K. 2020. Should you delete TikTok? Here's what experts say about the app Trump wants to ban. The Guardian. 16 July, https:/www.theguardian.com/technology/2020/jul/16/tiktok-video-sharing-app-should-youdelete-it (22.06.2021).

Stanford Encyclopedia of Philosophy. brw. https://plato.stanford.edu/entries/ identity-personal (10.12.2020).

Report on the short video users. https://bg.qianzhan.com/report/detail/1909091 648561802.html (10.02.2021).

Rosenthal, R. and Jacobson, L. 1968. Pygmalion in the classroom. New York: Holt, Rinehart and Winston.

Siegler, M.G. 2020. Interpersonal computing. https://500ish.com/interpersonal-computing-ad88f23bf3a7 (19.01.2021).

Smith, S.W. and Wilson, S.R. 2010. Evolving trends in interpersonal communication research. In: Smith, S.W. and Wilson, S.R. eds. New directions in interpersonal communication research. Thousand Oaks: SAGE, pp. 1-23.

Sokal, U. 2000. Wybrane aspekty kształtowania się tożsamości człowieka w rodzinie. Roczniki Socjologii Rodziny. XII, pp. 49-55.

Stanton, K., Ellickson-Larew, S. and Watson, D. 2016. Development and validation of a measure of online deception and intimacy. Personality and Individual Differences. 88, pp. 187 - 196.

Stewart, J. and Logan, C. 1998. Together. Communication interpersonally. New York: McGraw Hill.

Suls, J. and Wheeler, L. 2000. A selective history of classic and neo-social comparison theory. In: Suls, J. and Wheeler, L. eds. Handbook of social comparison: theory and research. New York: Kluwer Academic, pp. 3-19. Terras, M.M., Ramsay, J. and Boyle, E.A. 2015. Digital media production and identity: insights from a psychological perspective. E-Learning and Digital Media". 12 (2), pp. 128 - 146.

Thomas, L., Briggs, P., Hart, A. and Kerrigan, F. 2017. Understanding social media and identity work in young people transitioning to university. Computers in Human Behavior. 76, pp. 541-553.

Wachs, T.D. 1992. The Nature of Nurture. Newbury Park: SAGE.

Wang, G.A., Chen, H. and Xu, J. 2006. Automatically detecting criminal identity deception: an adaptive detection algorithm. IEEE Trans Syst Man Cybern Part A: Syst Hum. 36 (5), pp. 988-999. 